\title{
BIOЖECHNOLOGY
}

\section{FOUR GREAT MYTHS ABOUT JAPANESE BIOTECH}

$\mathrm{P}$

resident Reagan's trip to Japan in the late fall of last year came at a time of heightened tension between the U.S. and its strongest Far Eastern ally, a tension generated in part by Japan's phenomenal success in competing in two industrial areas that were formerly American strongholds: microelectronics and automobiles. Amidst concern about loss of the U.S. edge in a variety of technologies came commercial agreements between Japanese corporations and many of the major U.S. biotechnology firms and European multinationals. More recently, best-selling authors have cashed in on the growing mystique surrounding Japanese management, grossly exaggerating the efficiency of the production system. It is therefore fair to address some of the central myths about how Japan has positioned itself in the world of biotechnology and to ask whether that nation serves as a genuine threat to western leadership in this area.

One of the most destructive myths holds that Japanese $\mathrm{R} \& \mathrm{D}$ in biotechnology-based industries threatens to overtake western $R \& D$ programs, just as the Japanese succeeded in the microelectronics industry. Fortunately, this myth is not taken too seriously by some of the leading executives in U.S. biotechnology. However, it seems to be a fear among science and technology policy experts in Congress and the White House.

Japanese research in microelectronics was able to expand so rapidly because successful corporations could afford to invest money into their own, more advanced R\&D. Much of this needed capital was based upon longterm growth in international markets. The Japanese pharmaceutical and beverage industries, the main source of biotechnological expansion in that country today, have not enjoyed the same rapid growth as their counterparts in microelectronics over the last 15 years, nor have they positioned themselves as successfully in the world marketplace. Many of the companies do not have the capital to invest in basic in-house research. It is difficult to substitute this lack of an in-house research base with techniques acquired from university labs for several reasons. University funds for basic biological research are scarce in Japan compared to the situation in the U.S. Furthermore, industrial consulting by top basic researchers is frowned upon by Japan's finest institutions, the product of an academic tradition that considers applied research to be inferior to basic science. Opportunities are expanding for industrial and academic scientists to exchange information, but it is far more difficult to bridge basic and applied research in Japan than it is in many western countries. Although Japanese scientists are rapidly acquiring knowledge of basic techniques from the West, Japanese industrialists have explained that this is more a way of catching up and overcoming a deficiency in their system than it is a strategy of stealing time or taking unfair advantage in a product development race. Although there is no doubt that the Japanese have developed a national strategy to achieve world status in biotech, their ability to succeed is not as clear as some industry watchers imagine.

This brings us to a second myth, the idea that an international industrial race in biotechnology-that will have important implications for the U.S. economy-is already taking place between Japan and the United States. At least for the foreseeable future, Japanese and American biotech-based industries will be competing more strongly in the Japanese domestic market than in any international scheme. In the pharmaceutical industry, for example, Japan has only one world-class pharmaceutical company and, according to a 1980 study, a pharmaceutical trade deficit of over a half billion dollars. Analysis of the major agreements between foreign specialty firms and Japanese corporations reveals that most agreements only concern marketing rights or transfer of technology for product development for Japanese markets. The idea of technology transfer as a threat to U.S. firms makes little sense in Japan, where firms must compete fiercely among themselves to gain even a share of their home markets from foreign multinationals. If the Japanese have shown greater ability to refine and apply basic techniques learned from the West than to develop innovative laboratory techniques, then the so-called threat to American and European domestic markets is remote. It is far easier for Japanese corporations to develop products for their established home markets using techniques pioneered in other countries than to compete head-on in countries where the techniques were established years earlier.

Another myth about the growth of Japanese technology, a myth perpetuated in part by various U.S. goverment reports on the subject, is the idea that the Japanese will excel by taking unfair advantage of the openness of the U.S. research communities. Japanese universities and corporations regularly send representatives to train in some of the finest biotechnology laboratories. It is also true that Japanese researchers are renowned for their ability to commit to memory information gathered at western scientific meetings and for photographing endless slide presentations while western scientists watch with awe and some amusement. These phenomena are due to the fact that the Japanese realize they must rapidly build their laboratory capabilities to succeed in biotechnology. With notable exceptions in some food and agricultural areas, Japanese research needs to develop a base in the area of overlap between what is conveniently labeled "basic" and "applied" research in the West. Japanese universities and symposium organizers would probably be quite eager for more western scientists to visit and participate in their laboratories, at least on a temporary basis. This initiative must come from western nations once the areas of advanced Japanese biotechnology are clearly identified; the exchange of research information may never be truly reciprocal, however, since the Japanese areas of greatest interest in the next decade will probably remain in the proprietary fermentation processes developed by industry.

The stationing of Japanese scientists abroad and the relative lack of Westerners in Japanese laboratories is due in part to the country's geographic isolation and in part to the strong nationalistic tendencies of its people. The sheer Continued on page 93 
PATENTS (Continued from page 95)

deoxyhypoxanthine. The compounds are useful in the synthesis of a predetermined sequence of RNA with T4 RNA ligase (see above). The preparation of the compounds involves reacting the pyridine salt of adenosine $5^{\prime}$ monophosphate with the nucleoside $5^{\prime}$ phosphate $2^{\prime}-3^{\prime}$ cyclic phosphate. The product is isolated and treated with an enzyme that cleaves the $2^{\prime}$ phosphooxy bond to give the compound, which has the terminal phosphate group on the $3^{\prime}$ carbon of the nucleoside.

\section{EDITORIAL (Continued from page 7)}

cost of travel to "international" meetings in Europe and the U.S. is a great barrier to even the finest academic scientists in Japan. It is far more efficient to send young scientists to train at NIH or Cold Spring Harbor for a year than to spend the equivalent amount of money to travel to four western meetings annually.

When evaluating this policy of stationing Japanese scientists in foreign laboratories, Westerners should also note that there are laws and customs in Japan that make it nearly impossible for the Japanese to benefit from inviting foreign scientists to work and teach in their home settings. Racial pride and tradition make tenure at a major university or advancement in a Japanese research corporation an impossible goal for a westerner in Japan, further isolating the Japanese from the world scientific community. Perhaps this discrimination seems unfair, but it poses a far greater disadvantage to the Japanese than to western research efforts.

A final great myth about Japanese biotechnology that casts a spell over some industrialists is the idea that the Japanese have locked into a way of managing people that will propel them into world leadership in any innovative new technology. The Japanese have demonstrated brilliance in acquiring, developing, and refining applied biological methods, approaching and even surpassing some of the finer western efforts in selected areas of product development. But the system that efficiently builds microchips and random access memories does not necessarily foster creativity in biotechnology. In its special April issue on Japanese biotechnology, this journal will explore the Japanese industrial tradition, founded upon a system of receiving and building on the wisdom of its elders. It is a system that provides stronger rewards for loyal service than for blind achievement, a way of conducting $R \& D$ that seems to frustrate the types of young minds who have helped build the U.S. and European biotechnological base. One of the greatest challenges for the development of applied biology in Japan will be to encourage and give more autonomy to the younger scientists who have the skill and energy to pursue long-term, applications-oriented research. Success in this effort may require that some of the long-cherished Japanese management policies be abandoned for the acceptance of western methods of innovation.

It is in the common interest to explore and destroy the myths that create suspicion and inhibit collaboration between Japanese and western efforts. The long, tense history of ambivalence that has characterized relations between Japan and the major western powers must defer to the notion of world economic progress that can be achieved through collaboration in biotechnology.

\section{- Christopher G. Edwards}

\section{COMMENTARY (Continued from page 27)}

alpha-fetoprotein and carcinoembryonic antigen (CEA), shed by testicular and colorectal cancers, respectively, provide clinicians with an accurate measure of the size of a tumor. Appropriate assays are now beginning to emerge.
And as Dr. Karol Sikora points out, monoclonal antibodies are also set to bring a mini-revolution in histology laboratories. "The easy detection of cancer cells in smears prepared from body secretions such as sputum and vaginal mucous could rapidly lead to automated cytological diagnosis," he writes, "thus reducing its costs and making it available to a wider range of patients" (Nature, 1983, 304:97).

The greatest prize of all, of course, would be a means of fabricating "magic bullets" to destroy malignant tissue in situ. Researchers at Lilly Industries Ltd. in Britain have had initial success in using a CEA antibody, linked with the cytotoxic drug vindesine, to attack human colorectal tumors implanted in mice. Similar, encouraging signs have been reported elsewhere. And as Dr. Reto Obrist of the University Hospital, Basel, Switzerland, observed recently in Trends in Pharmaceutical Sciences (1983, 4:375), once such an approach is thoroughly proven, there will be a double benefit. If highly toxic molecules can be delivered precisely where they are needed, then many potent compounds will once again be candidates for clinical use. The defeat of drug toxicity could prove to be one of the unexpected bounties from the era of the monoclonals. $\boldsymbol{Z}$

\section{FINAL WORD (Continued from page 4)}

for example, computer-controlled fermentations-it should be possible to reduce the manufacturing costs of several high-priced antibiotics from the $\$ 30$ per pound to the $\$ 10$ per pound range. For a typical antibiotic like erythromycin (450 tons per year sales worldwide in 1974) this could represent a profit opportunity of $\$ 18$ million per year.

Similarly, the manufacturing costs for many of the amino acids can be reduced substantially through recombinant DNA and biochemical engineering. For example, a $\$ 5$ per pound reduction in cost for the amino acid phenylalanine (used in aspartame) is entirely reasonable to expect. Given estimates of sales for 1984 in the 2.5 million pound range, such a cost reduction would result in a profit opportunity of $\$ 12.5$ million per year.

For protein products, the manufacturing cost can be expected to be higher because the yield per unit volume of fermentation broth is usually less than for non-proteins, and product purification costs will generally be higher (due in part to the delicate nature of most proteins). At the low end, production costs can be expected to range from $\$ 5$ per pound to $\$ 35$ per pound when yields are good and purification is not critical or problematic. When extremely high purity is required or yield problems exist, production costs could easily be 10 times greater, or $\$ 350$ per pound.

The cost of production of protein products can be lowered from the high to the low ranges using recombinant DNA to increase yields and to aid in purification (by developing strains which secrete the product into the medium, for example). Such reduction in costs from several hundred dollars per pound to under a hundred dollars per pound represents significant opportunities for products in markets of even modest volumes.

I have used these simple examples of existing products to illustrate the point that it is possible to quantify real and current business opportunities for recombinant DNA genetic engineering without relying on dreams of blue-sky breakthroughs. While I believe that many of the exciting opportunities do reside in the future, with new products developed from the use of recombinant DNA technologies in agriculture, pharmaceuticals, and many other industries, the fact is that the recombinant DNA industry represents a real business opportunity right now and is not just another South Sea Bubble. 